\title{
Identity \& The Globalization of Nusantara
}

\author{
Suyatno Ladiqi ${ }^{1}$, Mohd Afandi Salleh ${ }^{2}$, Baiq Wardhani ${ }^{3}$, \\ Vinsensio Dugis ${ }^{4}$, Ismail Suardi Wekke ${ }^{5}$ \\ \{yatno.ladiqi@gmail.com¹, afandisalleh@gmail.com², baiq.wardhani@gmail.com ${ }^{3}$ \\ iswekke@gmail.com ${ }^{5}$. \\ ${ }^{1,2}$ Faculty of Law \& International Relations, Universiti Sultan Zainal Abidin, Terengganu, Malaysia

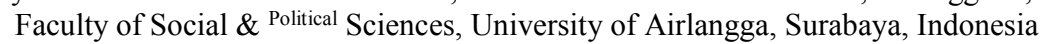 \\ ${ }^{5}$ STAIN Sorong, Papua, Indonesia
}

\begin{abstract}
The phenomenon of globalization in Nusantara actually was happened for long time ago. There is international trade between Nusantara and some countries in Asia and Europe. The meetings between traders in that era reflected the encounter of different civilizations as well as, that was able to transcend geographical and cultural boundaries. This paper would like to seek for an explanation about the phenomenon of globalization which Nusantara is taking a pivotal role in international trade. There are a lot of goods traded in that time, such as spices as a mainstay product. Important to explore the glory of Nusantara since, regarding modern era, identity must be supported by strong root history through shared memory and experience. Nusantara must be reinvented as a strong provision to strengthen national identity which is increasingly threatened by modernization.
\end{abstract}

Keywords: Nusantara, globalization, identity, maritime nation

\section{Introduction}

The phenomenon of globalization in Nusantara actually was happened for long time ago, in particular before the modern era. There is international trade between Nusantara and some countries in Asia and Europe. The meetings between traders in that era reflected the encounter of different civilizations as well as, that was able to transcend geographical and cultural boundaries. This history showed how is important the sea as a big part of Nusantara people to mobilize goods and services as a pivotal transportation route in the world.

There are many pieces of evidence that showed how spices from Nusantara is needed by European people. The trader from Gujarat, India and Arab also became an important hub to connect Nusantara and other countries. The important thing is spices Nusantara became a magnet of international trade for a long time. Until the colonialism era, spices still become the main reason why western people finally conquer Nusantara.

The history also shows how the glory of the sea of Nusantara, which in turn met with destruction along with the arrival of colonial states, such as Portuguese, Netherland, and British. After that, everything about the glory of Nusantara as if vanished in the earth. During colonialism era, the concept of Nusantara disappeared for a while and then surfaced again at intervals of hundreds of years, until it swamped newspaper reports, company directories, policy briefs, and scholarly articles when it's almost magical qualities were (re) discovered in the twentieth and twenty-first centuries [1].

This paper would like to seek for an explanation about the phenomenon of globalization which Nusantara is taking a pivotal role in international trade. There are a lot of goods traded 
in that time, such as spices as a mainstay product. Important to explore the glory of Nusantara since, regarding modern era, identity must be supported by strong root history through shared memory and experience. Nusantara must be reinvented as a strong provision to strengthen national identity which is increasingly threatened by modernization.

\section{Globalization as An Old Phenomenon}

Understanding the globalization as an explanatory concept of modern phenomena today is usually always associated with the sophistication of civilization where technology is an important aspect. However, the basic understanding of globalization actually relies on the phenomenon of the movement of people and goods on a world scale. According to Held \& McGrew [2], globalization has an undeniably material aspect in so far as it is possible to identify, for instance, flows of trade, capital and people across the globe. These are facilitated by different kinds of infrastructure - physical (such as transport or banking systems), normative (such as trade rules) and symbolic (such as English as a lingua franca) - which establish the preconditions for regularized and relatively enduring forms of global interconnectedness. Rather than mere random encounters, globalization refers to these entrenched and enduring patterns of worldwide interconnectedness. But the concept of globalization denotes much more than a stretching of social relations and activities across regions and frontiers.

The point is globalization has the main characteristic of people and goods encounter in trade scheme across the globe. From this understanding then raise some version to state when globalization begin. Andre Gunder Frank in his well-known Re-Orient [3] argued that globalization was there well before 1500. Frank's conclusion on global trade is that Asia and especially China dominated the global economy. He also underpins the importance of trade within Southeast Asia in particular and global trade in general by listing some large tradedependent cities in Southeast Asia.

Another scholar such as Dennis Flynn and Arturo Giraldez, claims that globalization began in 1571 when the Spaniards settled down in Manila in the Philippines and opened up trade. At meanwhile Christopher Baily claims that globalization started with the collapse of $18^{\text {th }}$-century regimes. Baily defines as 'modern globalization' and sees it as a process based on colonialism and imperialism, and the concept of free trade [4].

The definition and timeline of the beginning of globalization above show how the appropriate of Nusantara is discussed in the context of involvement with old globalization. The dynamics of Nusantara trade is in harmony with Frank's argument that for a long time the people of Southeast Asia (Nusantara) have been intensely involved in international trade. Therefore this paper is more in line with Frank's argument which states that globalization began before 1500 .

\section{The Globalization of Nusantara: Trade, Glory And The Sea}

The term Nusantara originally came from two Sanskrit words, namely Nusa which means 'island' and Antara which means 'in between' or 'included'. In the ancient Javanese texts, the nūsāntara can be translated as 'other islands' [5]. The best-known written document is the Pararaton, and Negarakertagama, a Javanese text on the Javanese kingdoms of Singhasari and Majapahit [1]. This text reports that Gadjah Mada, the prime minister of the Majapahit Empire, swore an oath (sumpah palapa) in 1334 that he would refrain from using spices with his food until a number of kingdoms in the Nusantara on the fringes of the Majapahit Empire were subdued. Given the importance of sambal for all Javanese dishes, this oath must, indeed, 
have been taken very seriously. The list of realms illustrates, if not the extent of Majapahit, then the total area covered by the concept of Nusantara, or at least the outlying maritime areas outside Java [1]. In the modern era, Nusantara denotes a unified territory composing entire indigenous countries in the region currently called Southeast Asian. The term is still in common among the natives of Indonesia, Malaysia, Brunei Darussalam, Singapore, and south Thailand [6].

In its development, the term Nusantara was used more like the identity of a nation that wanted to be built against the colonialist hegemony. Douwes Dekker, Ki Hajar Dewantoro and Soekarno were Indonesian independence figures who echoed the term Nusantara as anti-thesis of colonialism. This can be understood because the glory of Nusantara which has a global level has become an inspiration for the people in the Southeast Asian region, especially in the days of independence.

\subsection{Trade \& The Glory}

One example of the globalization Nusantara recorded by ancient history is the body of the corpse of the Ancient Egyptian king, Pharaoh. The body is preserved using camphor (Dryobalanops aromatica). In the world, there are only three areas that produce camphor, namely Sumatra, the Malay Peninsula, and Borneo [7]. This shows that world trade has been carried out by Nusantara people in ancient times.

Furthermore, Nusantara more often made trade contacts with India around the 3rd century. After losing the gold source of the Siberian caravans, India began importing Roman gold. However, during the reign of Emperor Vespasian in the Roman era, the importation of the gold currency was stopped for reasons of Roman economic stability. This prompted India to find a source of gold to other regions, namely Nusantara. While China is more interested in making trade contacts with areas in West Asia through the Funan trade route. China just entered the Nusantara trade route in the 5th century, because Nusantara began to supply commodities equivalent to those offered by traders from West Asia. For example incense, sandalwood, camphor, and spices [8].

The intensity of international trade in Nusantara is quite high because traded products are indeed the world's main needs. Regarding summarized by Anthony Reid [9] that the pattern of exchange in this age of commerce was for Southeast Asia to import cloth from India, silver from the Americas and Japan and copper-cash, silk, ceramics and other manufacturers from China, in exchange for its exports of pepper, spices, aromatic woods, resins, lacquer, tortoiseshell, 'pearls, deerskin, and the sugar exported by Vietnam and Cambodia.

Essentially it was a pattern of east-west exchange of goods within the Indonesian archipelago with Javanese rice being carried everywhere. The central fact of Indonesian trade was that two major products-pepper and spices-were located at the two extremities of the archipelago. Pepper was produced in Sumatra, Malaya, West Java and Borneo. Spices-cloves, nutmeg and mace-were available only in the eastern island groups of the Moluccas and Bandas. Java produced rice, salt, salt-fish and a variety of foodstuffs as well as some cotton, thread, and textiles. Rice and other Javanese product were carried by Javanese traders and junk-owners to Sumatra to have them exchanged for pepper and other foreign goods. Pepper was then taken to Java and further on to Bali in order to collect in exchange Balinese cotton fabrics which were in great demand in the Spice Islands. In the final stage, the Javanese sailed out to the Moluccas and Bandas carrying rice, and other Javanese products, Balinese cloth, along with Indian textiles and Chinese porcelain, silk and small coins. A marked feature of Indonesian trade was the intertwining of inter-island and international trade [10]. 
A Chinese reference originating in the early 13th century illustrates the trade that occurred in Srivijaya. The Srivijaya kingdom is one of Nusantara kingdoms that has been able to control trade and shipping traffic from the western region to China. This is inseparable from the strategies possessed by Srivijaya in building its power [11]. In the 7th century until the mid-12th century, the Srivijaya kingdom still showed progress in trade. The end of the 12th century, Srivijaya showed a decline and the process was proven in the 13th century. The decline of the Srivijaya Empire was exploited by Islamic traders to gain more profit in trade in Nusantara. This then placed Nusantara in increasingly crowded world trade traffic and provided benefits for the ports in the archipelago to develop further, one of which was Malacca [11].

The glory of the Nusantara trade, of course, is supported by its sea power. The glory of the sea of Nusantara became a catalyst not only for the trading world but also for the expansion and conquest of the region as a symbol of political might. Majapahit's marine fleet, for example, is widely known to be able to conquer areas with hundreds of ships.

Nusantara seafarers in historical evidence are known as sailors whom Robert Dick-Read [12] referred to as sailors outside the Persians, Arabs, and Indians, who traded with Egypt and Rome. They were also not Chinese sailors because Chinese sailors only sailed to Southeast Asia around the 7th century. The seafarers are Austronesian sailors. This opinion was supported by Stephen Oppenheimer that the Austronesian seafarers came from Nusantara. Even more in detail, Oppenheimer [13] examines the origin of Austronesian languages which are geographically located in Nusantara.

In the record of the Kingdom of $\mathrm{Wu}$ and Faxian, from China in 414 showed that Java was the center of world trade due to trade and shipping of large ships. Even the ships exceeded than the ship of Cristophorus Columbus, the first European ship to cross the ocean in 1492. Columbus ships were only able to accommodate 88 crew members[14]. While the Kun Lun Po, as Nusantara sailors ship, can accommodate 600 people [15].

Majapahit as a symbol of the Nusantara kingdom showed its strong power by continuing the prosperity of the previous Javanese King, King Airlangga. Majapahit's victory over the Mongols and intensive relations with Yawana (Arabic), as explained in Nagarakertagama 15.1, reaffirmed as the controller of the Asian commercial zone. Nagarakertagama even noted that the territory that Majapahit had joined included Nusantara, Desantara (China), Dwipantara (China \& India). Prapanca's notes reinforce information on the Jayanegara II Inscription in 1323, which called Majapahit combining Indian Territory into Java. This historical record shows that the national maritime country did not experience a setback until the end of King Majapahit. The main role of Java as the center of the national maritime kingdom is to protect the marine trade routes as the main trade route and eliminate the threat of sea lanes [7].

\section{Identity and Dignity of Nusantara}

Francis Fukuyama [16] stated identity in a specific sense that helps us understand why it is so important to contemporary politics. Some of ethnic identify their identities according to their place of residence [17]. Identity grows, in the first place, out of a distinction between one's true inner self and an outer world of social rules and norms that do not adequately recognize that inner self's worth or dignity. Individuals throughout human history have found themselves at odds with their societies. But only in modern times has the view taken hold that the authentic inner self is intrinsically valuable, and the outer society systematically wrong and unfair in its valuation of the former. It is not the inner self that has to be made to conform to society's rules, but society itself that needs to change. 
The inner self is the basis of human dignity, but the nature of that dignity is variable and has changed over time. In many early cultures, dignity is attributed only to a few people, often warriors who are willing to risk their lives in battle. In other societies, dignity is an attribute of all human beings, based on their intrinsic worth as people with agency. And in other cases, dignity is due to one's membership in a larger group of shared memory and experience.

The glory and pride of Nusantara should be able to become a shared memory and experience. Historical data has shown how important the influence of Nusantara in world civilization. It's just that along with the arrival of the invaders, the identity and dignity of the Nusantara people began to collapse. Nusantara values were reinventing when entering the period of the end of colonialism. What was done by Douwes Dekker, Ki Hajar Dewantara and Soekarno by popularizing the term Nusantara was a great effort to bring back the pride of the old Nusantara.

Pride as a maritime country should be able to become the identity because history has proven that the role of Nusantara is extraordinary in the arena of trade and international relations. The reality that Southeast Asia today consists of island countries must be accepted as a necessity of identity as an archipelagic maritime country connected by the ocean. So that identity can be connected with proud historical roots.

Precisely, the pride of Nusantara can be seen from the cultural heritage that until now still exists and has global influence. Tempe is one of them. As cakes made from soybeans through the process of fermentation and popular food (volk's voedsel), Tempe is recorded in the Encyclopedia van Nederlandsch Indie in 1922. The discovery of tempe in its essence is closely related to the production of tofu in Java because both are made from soybeans. Not only the same ingredients but maybe also the discovery of tempe directly related to the production of tofu. Soybeans themselves have been known in China for 5,000 years, while they know, in the same country, hundreds or perhaps thousands of years have been known [18].

Tempe that is often underestimated by people turns out to save efficacy that has been recognized worldwide. The specialty of Tempe which has been known since the mid-1980s has actually made people in various countries such as the Netherlands, America, Japan, Malaysia, and Singapore, consume tempeh as diet food. Tempeh has a softer texture than soybeans, because tempeh moulds digest the matrix between soybean cell seeds, while enzymes produced by mould during fermentation cause changes in protein, fat, and carbohydrates. According to Darwin Karyadi who is also a former Head of the Nutrition Research and Development Center Indonesia, isoflavone levels in soybeans increase when fermented. Therefore, tempe becomes very rich in isoflavones. Isoflavonoids apparently not only prevent cell activity leading to malignancy, but also affect the metabolism of steroid hormones, reduce cholesterol and triglycerides, and protect liver cells from exposure to toxic compounds [19].

Other Nusantara heritage is still spread in the culture of modern society in Southeast Asia and the world. Call it clove cigarettes, batik art, martial arts, puppets, dance, gamelan or herbal medicine. These heritages not only still exist but also it has a degree of influence that must be recognized today is quite global. That is identity and dignity which should be the life choices of people in Nusantara now.

\section{Conclusion}

The glory of Nusantara in the past in the context of globalization should be placed in a framework of thinking for the future inspired by the struggle, the thought of the ancestors. Strong identity and dignity can be the foundation for the life of the nation and state in this 
modern era. At least there are some things that can be underlined in this paper. First, how to build a dignified nation culture based on the noble values of the nation so that it called it as a personality. This becomes important amid the swift influx of Western values that erode local culture. Second, the importance of realizing the existence of a maritime nation living in an archipelago. The success of the colonials who isolated the nation in Nusantara became a land nation that no longer had wide access to the ocean. Even the colonials succeeded in changing the perspective and attitude of Nusantara people "hostile" to the oceans as if the ocean was separating the unity of the islands. This is the real challenge of this nation today. ***

\section{References}

[1] H.-D. Evers, "Nusantara: History of A Concept," J. Malays. Branch R. Asiat. Soc., vol. 89, no. 1, pp. 3-14, 2016.

[2] D. Held and A. McGrew, Globalization As An Empire. The Global Transformations Reader: An Introduction To The Globalization Debate. Cambridge: Polity Press, 2003.

[3] A. G. Frank, ReORIENT: Global economy in the Asian age, Kindle. London: University of California Press, 1998.

[4] D. O. Flynn and A. Giráldez, "Cycles of silver: Global economic unity through the mid-eighteenth century," J. World Hist., vol. 13, no. 2, pp. 391-427, 2002.

[5] P. J. Zoetmulder and S. O. Robson, Old Javanese-English dictionary. The Hague: Nijhoff, 2 Vols, 1982.

[6] A. OdM, Z. Zakaria, and W. A. F. bin W. Hashim, "Nusantara: Delineating Its Authentic Map Based on Indigenous Sources," Intellect. Prop. Rights Open Access, vol. 4, no. 2, pp. 1-4, 2016.

[7] I. D. Nugroho, Majapahit peradaban maritim ketika nusantara menjadi pengendali pelabuhan dunia. Jakarta: Suluh Nuswantara Bakti, 2010.

[8] M. D. Poesponegoro and N. Notosusanto, Sejarah nasional Indonesia Jilid II. Jakarta: Balai Pustaka, 2009.

[9] A. Reid, Southeast Asia in the age of commerce 1450-1680. Vol. 2: Expansion and Crisis. New Haven: Yale University Press, 1993.

[10] A. Das Gupta, Indian merchants and the decline of surat: c. 1700- 1750. Wiesbaden: Steiner, 1979.

[11] A. R. Hamid, Sejarah Maritim Indonesia. Jogjakarta: Penerbit Ombak, 2013.

[12] R. Dick-Read, Penjelajah Bahari: Pengaruh Peradaban Nusantara di Afrika. Bandung: PT. Mizan Pustaka, 2008.

[13] S. Oppenheimer, Eden In The East. Phoenix: Orion, 1999.

[14] K. Yuanzhi, Muslim Tionghoa Cheng Ho: Misteri Perjalanan Muhibah Di Nusantara. Jakarta: Pustaka Populer Obor, 2005.

[15] W. P. Groeneveldt, Nusantara Dalam Catatan Tionghoa. Jakarta: Tira Pustaka, 2009.

[16] F. Fukuyama, Identity: The Demand for Dignity and the Politics of Resentment. Farrar, Straus and Giroux, 2018.

[17] F. Firdaus, "Relasi Etnik dan Identitas Kewargaan di Kota Binjai," in Kota-Kota di Sumatra; Enam Kisah Kewargaan dan Demokrasi, H. Budiman, Ed. Jakarta: The Interseksi Foundation, 2012, pp. 133-190.

[18] Onghokam, "Tempe Sumbangan Jawa Untuk Dunia," in Seribu Tahun Nusantara, J. B. Kristanto, Ed. Jakarta: PT. Kompas Media Nusantara, 2000.

[19] A. Aristiarini, "Mukjizat tempe untuk kesejahteraan," in Seribu Tahun Nusantara, J. B. Kristanto, Ed. Jakarta: PT. Kompas Media Nusantara, 2000. 
